\title{
Edema Rating 1
}

National Cancer Institute

\section{Source}

National Cancer Institute. Edema Rating 1. NCI Thesaurus. Code C121311.

Mild edema (slight but definite). 